
Upload this completed form to website with submission

\begin{tabular}{|c|c|}
\hline ARTICLE INFORMATION & Fill in information in each box below \\
\hline Article Type & Research article, Review article or Short Communcation \\
\hline Article Title & $\begin{array}{l}\text { The Quality Characteristics of Ready-to-Eat Empal Gentong affected by } \\
\text { meat pre-cooking }\end{array}$ \\
\hline Running Title (within 10 words) & Ready-to-Eat Empal Gentong affected by meat pre-cooking \\
\hline Author & 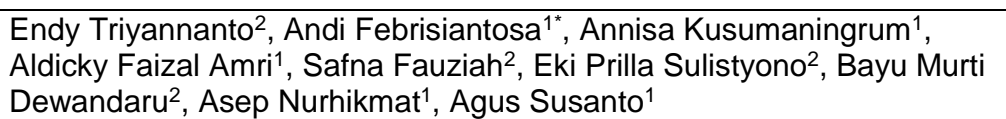 \\
\hline Affiliation & $\begin{array}{l}\text { 1Research Division for Natural Product Technology, Indonesian Institute } \\
\text { of Science, Gunungkidul, DI Yogyakarta, Indonesia } \\
\text { 2Department of Animal Products Technology, Animal Science Faculty, } \\
\text { Universitas Gadjah Mada, Indonesia }\end{array}$ \\
\hline \multicolumn{2}{|l|}{$\begin{array}{l}\text { Special remarks - if authors have additional } \\
\text { information to inform the editorial office }\end{array}$} \\
\hline $\begin{array}{l}\text { ORCID (All authors must have ORCID) } \\
\text { https://orcid.org }\end{array}$ & $\begin{array}{l}\text { Endy Triyannanto (https://orcid.org/0000-0002-1682-2186) } \\
\text { Andi Febrisiantosa (https://orcid.org/0000-0001-8664-4189) } \\
\text { Annisa Kusumaningrum (https://orcid.org/0000-0001-7073-5502) } \\
\text { Aldicky Faizal Amri (https://orcid.org/0000-0002-8391-6086) } \\
\text { Safna Fauziah (https://orcid.org/0000-0003-4352-5256) } \\
\text { Eki Prilla Sulistyono (https://orcid/0000-0001-9606-2369) } \\
\text { Bayu Murti Dewandaru (https://orcid/0000-0001-9606-2369) } \\
\text { Asep Nurhikmat (https://orcid/0000-0002-2447-0395) } \\
\text { Agus Susanto (https://orcid/ }\end{array}$ \\
\hline $\begin{array}{l}\text { Conflicts of interest } \\
\text { List any present or potential conflict s of } \\
\text { interest for all authors. } \\
\text { (This field may be published.) }\end{array}$ & The authors declare no potential conflict of interest. \\
\hline $\begin{array}{l}\text { Acknowledgements } \\
\text { State funding sources (grants, funding } \\
\text { sources, equipment, and supplies). Include } \\
\text { name and number of grant if available. } \\
\text { (This field may be published.) }\end{array}$ & $\begin{array}{l}\text { The author would like to thank the Ministry of Finance's Education Fund } \\
\text { Management Agency for funding this research through the National } \\
\text { Research Priority Program (RISTEK BRIN LPDP) } 2020 \text {. }\end{array}$ \\
\hline $\begin{array}{l}\text { Author contributions } \\
\text { (This field may be published.) }\end{array}$ & $\begin{array}{l}\text { Conceptualization: Febrisiantosa A, Triyannanto E., Kusumaningrum A. } \\
\text { Data curation: Febrisiantosa A, Triyannanto E., Fauziah S. } \\
\text { Formal analysis: Fauziah S, Sulistyono EP, Dewandaru BM } \\
\text { Methodology: Febrisiantosa A, Triyannanto E., Amri AF. } \\
\text { Software: Triyannanto E. Sulistyono EP, Dewandaru BM } \\
\text { Validation: Febrisiantosa A, Triyannanto E, Kusumaningrum A. } \\
\text { Investigation: Nurhikmat A, Susanto A, Amri AF, Kusumaningrum A. } \\
\text { Writing - original draft: Febrisiantosa A, Triyannanto E, Fauziah S. } \\
\text { Writing - review \& editing: Febrisiantosa A, Triyannanto E, Fauziah S. }\end{array}$ \\
\hline $\begin{array}{l}\text { Ethics approval (IRB/IACUC) } \\
\text { (This field may be published.) }\end{array}$ & $\begin{array}{l}\text { This article does not require IRB/IACUC approval because there are no } \\
\text { human and animal participants. }\end{array}$ \\
\hline
\end{tabular}

5

6 CORRESPONDING AUTHOR CONTACT INFORMATION

\begin{tabular}{|l|l|}
\hline $\begin{array}{l}\text { For the corresponding author } \\
\text { (responsible for correspondence, } \\
\text { proofreading, and reprints) }\end{array}$ & Fill in information in each box below \\
\hline First name, middle initial, last name & Andi Febrisiantosa \\
\hline $\begin{array}{l}\text { Email address - this is where your proofs } \\
\text { will be sent }\end{array}$ & andi.febrisiantosa@gmail.com \\
\hline Secondary Email address & andi001@lipi.go.id \\
\hline Postal address & 55861 \\
\hline
\end{tabular}




\begin{tabular}{|l|l|}
\hline Cell phone number & +6281802395805 \\
\hline Office phone number & +62274392570 \\
\hline Fax number & $+62274-391168$ \\
\hline
\end{tabular}

8 


\section{The Quality Characteristics of Ready-to-Eat Empal Gentong affected by meat pre-} cooking

\section{Abstract}

The purpose of this research was to examine the effectiveness of pre-cooking treatments on the quality characteristics of ready-to-eat (RTE) empal gentong. Raw beef meat was precooked in water bath at $90^{\circ} \mathrm{C}$ for $0 \min (\mathrm{C}), 10 \min (\mathrm{T} 1), 20 \mathrm{~min}(\mathrm{~T} 2)$, and $30 \mathrm{~min}(\mathrm{~T} 3)$ prior to retorting process at $121^{\circ} \mathrm{C}$ and pressure at 0,7 bars. Results showed that precooking treatments in all treated samples could reduce fat contents in empal gentong's meat by $0.02 \%$ (T1), $0.28 \%$ (T2), and $1.13 \%$ (T3) respectively. Highest precooking time tends to increase the $\mathrm{pH}$ and $\mathrm{CIE} \mathrm{a}^{*}$ values. However, CIE $\mathrm{b}^{*}$ values, water holding capacity (WHC), and sensory analysis were not affected by pre-cooking duration which must have been affected by sterilization process after precooking. In conclusion, pre-cooking treatment before sterilization in producing empal gentong is a probable technique to reduce its fat content and improve its physical quality. A specific treatment at $90^{\circ} \mathrm{C}$ for $10 \mathrm{~min}$ is recommended to achieve optimum quality of ready-to-eat empal gentong's meat. Keywords: pre-cooking, meat, ready-to-eat, empal gentong, quality characteristic

\section{Introduction}

Interest in traditional food products has grown in both developed and developing countries (Anders and Caswell 2009). As a country with diverse cultures and traditions, Indonesia has a variety of traditional foods (Rianti et al. 2018). Empal gentong, a traditional food originating in Cirebon, Indonesia, is meat prepared with mixed spices and coconut milk. However, consumers nowadays complain about fat droplets in the broth and the short shelf life of the product. Therefore, retort packaging, which involves sterilization at high temperatures, is used to produce ready-to-eat (RTE) empal gentong. 
The quality of RTE empal gentong meat was the focus of this study. Some small and medium level industries still use the conventional method of pre-cooking without a standard. However, several recent studies have aimed to reduce the fat content and improve the visual appeal of meat products. Triyannanto and Lee (2015) showed that precooking successfully improves the quality of Korean ginseng chicken soup, as judged by consumer acceptance. Furthermore, Manheem et al. (2013) reported that a cheap and simple pre-cooking process is important for extending the shelf life of food products. Accordingly, our study aimed to identify the optimal pre-cooking method for RTE empal gentong by evaluating the quality characteristics of the meat prepared using various precooking treatments.

\section{Materials and Methods}

Meat preparation and precooking treatment

Fresh beef meat was purchased from the local butcher's market in Yogyakarta City of Indonesia, and immediately brought to the laboratory. The fresh beef meat (longissimus dorsi) was cut into cubes with a size of $3 \times 3 \times 3 \mathrm{~cm}(\mathrm{LxWxH})$ to be prepared for precooking treatment. The meat samples were then packed with sealable PE plastics bag. The precooking process was carried out by heating the meat samples in the water bath at a temperature of $90^{\circ} \mathrm{C}$. There were four group treatment of pre-cooking time namely control/without pre-cooking (C), $10 \mathrm{~min}(\mathrm{~T} 1), 20 \mathrm{~min}(\mathrm{~T} 2)$ and $30 \mathrm{~min}$ (T3) of precooking time with five replications. The curry was separately prepared by mixing the coconut milk, spices, and hot water. The curry was heated at a temperature of $80-90^{\circ} \mathrm{C}$ for $45 \mathrm{~min}$.

\section{RTE Empal gentong preparation}


A total of $50 \mathrm{~g}$ meat cubes was introduced to multilayer retort pouch with a specific layer arrangement of PET / ALU / ONU / CPP, $16.0 \mathrm{~cm}$ x $22.9 \mathrm{~cm}(\mathrm{WxH})$ size. About $300 \mathrm{ml}$ of hot curry was poured into the pouch, then was sealed by using a continuous sealer machine. Afterward, the sterilization process was carried out using a retort machine

which was operated by holding a pressure of $10.15 \mathrm{psi}, 9 \mathrm{~min}$ until sterility value is obtained. After sterilization, a cooling process was carried out in room temperature water at $22-25^{\circ} \mathrm{C}$ for $10 \mathrm{~min}$. The RTE empal gentong samples were then analyzed.

$$
\mathrm{pH} \text { value }
$$

Ten grams of empal gentong's meat was chopped and then transferred into $40 \mathrm{~mL}$ of distilled water, homogenized at $10.000 \mathrm{rpm}$ for $60 \mathrm{~s}$ using a homogenizer. The $\mathrm{pH}$ values were measured using a pH meter attached with an electrode (Orion Star A111 Benchtop, Thermo Fisher Scientific Inc, Singapore). The pH value was performed in triplicate per treatment (Muhlisin et al. 2013).

\section{Tenderness}

Samples of empal gentong's meat with a thickness of $0.5 \mathrm{~cm}$ and $1.5 \mathrm{~cm}$ width were placed on the Warner-Bratzel instrument (Soeparno 2015)

\section{Water holding capacity}

The analysis of the water holding capacity (WHC) in this research using the method of (Hamm 1972). Samples in amount of 0.3 gr placed on filter paper and pressed between 2 glass plates, and then given $35 \mathrm{~kg}$ load for $5 \mathrm{~min}$. The area which absorbed water was then counted with planimeter. WHC then calculated with the following formula:

$$
\mathrm{mgH}_{2} \mathrm{O}=\frac{\text { wet area }(\mathrm{cm} 2)}{0,0948}-8
$$


The sample used for water content assay was $1 \mathrm{~g}$. Weighed samples then inserted into

filter paper and oven dried at $105^{\circ} \mathrm{C}$ for $24 \mathrm{~h}$ (Soeparno 2015).

$$
\begin{aligned}
\text { WHC } & =\frac{x+y-z}{x} \times 100 \% \\
\% \mathrm{WHC} & =\mathrm{TWC}-\% \text { free water }
\end{aligned}
$$

Where $\mathrm{X}=$ Sample weight; $\mathrm{Y}=$ filter paper weight; $\mathrm{Z}=$ Sample weight + filter paper weight after being oven; and TWC = Total Water Content.

\section{Cooking loss}

The analysis of the cooking loss in this research using the method of Bouton et al., (1972). The meat was cut in the direction of the fiber and weighed as much as $25 \mathrm{~g}$. Afterwards, the meat was put in polyethylene plastic and packed with a vacuum machine. The meat was cooked in a water bath at $90^{\circ} \mathrm{C}$ for $0 \mathrm{~min}(\mathrm{C}), 10 \mathrm{~min}(\mathrm{~T} 1), 20 \mathrm{~min}(\mathrm{~T} 2)$, and $30 \mathrm{~min}$ (T3) min. The meat was then cooled and removed from the polyethylene plastic and then wiped with a tissue and the final weight is weighed.

$$
\text { Cooking Loss }=\frac{x-y}{x} \times 100 \%
$$

Where $\mathrm{x}=$ initial weight; $\mathrm{y}=$ final weight

\section{Proximate analysis}

Chemical analysis method for this research were water, fat, protein, and collagen content by using a food scanner (FoodScan TM Meat Analyser; FOSS, Padova, Italy) with NIRS (Near Infrared Reflectance Spectroscopy) technology. Thirty grams of sample were grinded and checked in food scanner with a special petri dish. Samples checked in triplication (Triyannanto et al. 2019)

$$
\text { Sensory analysis }
$$


Sensory analysis following the method described by Triyannanto and Lee, (2015). The total of 11 male and female semi-trained panellists aged 17- 21 years conducted a sensory analysis for RTE empal gentong. Sensory procedures were explained in detail to the panellists before conducting a sensory test. A pack questionnaire was given to be filled during a sensory analysis. Every sample was labelled with 3 different numbers to decline the subjective score possibility. To support the sensory analysis lamp room with a 1,200lux brightness were applied. Panellists are required to rinse their mouth after the analysis for each different sample. These procedures were designed to avoid cross-contamination of the sensory characteristics in each sample. Furthermore, the panellist was obliged to fill the questionnaire that has been provided. Sensory analysis in this research was contained of four parameters namely, color, tenderness, taste, texture, and flavour. Parameter scales were set at; 5: very like, 4: Like, 3: plain 2: dislike, and 1: very dislikes.

\section{Statistical analysis}

SPSS Statistics (version 25.0; (IBM, 2017) for Windows Evaluation Version was used to analyze all data. The data were analyzed using one way analysis of variance and Duncan's multiple range test for significant differences $(\mathrm{p}<0.05)$.

\section{Results and Discussion}

$$
\mathrm{pH} \text { value }
$$

Table 1 shows that pre-cooking time significantly affected the $\mathrm{pH}$ value of the meat $\mathrm{p}$ $<0.05)$. The $\mathrm{pH}$ value was 6.31 in the control and tended to increase with longer precooking times. The $\mathrm{pH}$ values in this study might have been affected by the heating process, which causes amino acids to lose their carboxyl groups. A decrease in the number of acidic groups was also observed by Hamm and Deatherage (1960), who showed that 
ground longissimus dorsi muscle lost almost one-third of its carboxyl groups when heated at $20-70^{\circ} \mathrm{C}$ for $30 \mathrm{~min}$ in a water bath contained by a covered metal vessel.

\section{Water-holding capacity}

Table 1 shows that the pre-cooking time did not significantly affect the water-holding capacity of the meat $(\mathrm{p}>0.05)$. The water-holding capacity was dependent on the amount of denaturation of the meat protein. The absence of a significant effect was possibly caused by the complete denaturation of protein during the sterilization process at $121^{\circ} \mathrm{C}$, which resulted in a constant water-holding capacity among all treatments. High pressure thermal processing after pre-cooking results in complete protein denaturation. In accordance with this, Sun et al. (2016) reported that in beef, pork, and chicken, commercial sterilization at $121^{\circ} \mathrm{C}$ for 10 min leads to protein-bound water but does not significantly affect the protein and fat content in beef and pork. Moreover, Soeparno (2015) showed that myofibril protein coagulates at $30^{\circ} \mathrm{C}$ and completely denatures at $55^{\circ} \mathrm{C}$, which is lower than the commercial sterilization temperature. Furthermore, Gómez et al. (2020) reported that high pressure and temperature do not significantly affect the cooking loss rate or water-holding capacity.

\section{Tenderness}

The tenderness of the meat was measured by determining the content of connective tissue, such as collagen. As shown in Table 2, decreased penetrometer values indicated that tenderness increased significantly $(\mathrm{p}<0.05)$. Pre-cooking produced penetrometer values of $4.26 \mathrm{~kg} / \mathrm{cm}^{2}(\mathrm{~T} 1), 4.23 \mathrm{~kg} / \mathrm{cm}^{2}$ (T2), and $4.13 \mathrm{~kg} / \mathrm{cm}^{2}$ (T3), which were lower than those of the control $\left(6.40 \mathrm{~kg} / \mathrm{cm}^{2}\right)$. A lower penetrometer value objectively shows that less energy and pressure are required for chewing. Collagen hydrolysis during pre- 
cooking resulted in increased tenderness. Lawrie and Ledward (2006) reported that cooking affects meat structure, softening the connective tissue by converting collagen into gelatin. Moreover, Soeparno (2015) stated that tenderness reflects the amount of collagen present and that long boiling times cause changes in the structure of muscle proteins, especially actin and myosin. The breakdown of actin and myosin can influence the mechanical strength of connective tissue (Bouton and Harris, 1972).

\section{Cooking loss}

The cooking loss observed in each pre-cooking condition is presented in Table 2. An extrinsic factor that affected cooking loss was pre-cooking duration. Meat subjected to longer pre-cooking treatments tended to exhibit significantly greater cooking losses than those subjected to shorter treatments. Meat in the T3 group, pre-cooked for $30 \mathrm{~min}$, exhibited the greatest cooking loss. This loss might consist of water and other watersoluble components, such as proteins. High pre-cooking temperatures up to $90^{\circ} \mathrm{C}$ decreased the initial weight of the empal gentong meat by almost half. This result was in accordance with that found by Tornberg (2005), who stated that the greatest cooking loss in beef occurs at $60-80^{\circ} \mathrm{C}$, which is lower than the pre-cooking temperature used in our study. Hearne et al. (1978) also reported that higher endpoint temperatures result in greater cooking loss in bovine semitendinosus meat.

\section{Instrumental color}

The instrumental color values, CIE L* (lightness), $a^{*}$ (redness), and $b^{*}$ (yellowness), are presented in Table 1 . The CIE L* and $\mathrm{a}^{*}$ values of RTE empal gentong meat in the $\mathrm{T} 2$ group were lower than those in the $\mathrm{T} 1$ group, indicating that these values tended to decline with longer pre-cooking times $(\mathrm{p}>0.05)$. However, the highest values were 
observed in meat pre-cooked for 30 min $(\mathrm{T} 3)(\mathrm{p}<0.05)$. As reported by Muhlisin et al. (2013), chuncheon dalkalbi meat with a lower CIE L* value exhibits a darker color. The effect of pre-cooking time on the CIE $\mathrm{L}^{*}$ and $\mathrm{a}^{*}$ values of empal gentong meat in this study was not clear. Certain ingredients of RTE empal gentong, such as turmeric, ginger, and other herbs, which naturally tend to be yellow in color, might have been responsible for the CIE $\mathrm{L}^{*}$ and $\mathrm{a}^{*}$ values during processing. Longer pre-cooking time had no effect on the $\mathrm{CIE} \mathrm{a}^{*}$ value $(\mathrm{p}>0.05)$. It seemed that sterilization at $121{ }^{\circ} \mathrm{C}$ was responsible for more defects than the pre-cooking duration, which produced a non-significant CIE $\mathrm{b}^{*}$ value. Myoglobin, responsible for the red color of meat, turns grayish brown at $75^{\circ} \mathrm{C}$ (Hunt et al., 1999), which is lower than the pre-cooking temperature of $90^{\circ} \mathrm{C}$ and far lower than the sterilization temperature of $121^{\circ} \mathrm{C}$ used in this study. Moriyama and Takeda (2010) reported that myoglobin is mostly destroyed at $70-100^{\circ} \mathrm{C}$.

\section{Proximate composition}

Table 2 shows the proximate composition of RTE empal gentong subjected to the various pre-cooking times. Significant differences in moisture, protein, fat, and collagen were observed between the control and experimental groups $(\mathrm{p}<0.05)$. As shown in Table 2, the moisture content of the control was $67.16 \%(\mathrm{w} / \mathrm{w})$, but that of the T1, T2, and T3 groups was reduced by $1.54-5.92 \%$. The lower moisture content of the meat samples subjected to pre-cooking treatments might be related to the heat-induced denaturation of myofibrillar protein, which can adversely affect the water-holding capacity (Triyannanto and Lee 2015). This result is in accordance with the results shown in Table 1, which indicated greater cooking loss with longer pre-cooking duration.

The crude protein content of the control was $23.93 \%$, while that of the T1, T2, and T3 groups was reduced by $0.18-0.84 \%$. Cooking at a high temperature for a long time causes 
210 the protein content to decrease. Tornberg (2005) reported that the heating process results

211 in denaturation of myofibril proteins and changes in protein structure. In addition, the

212 soluble protein content decreases by approximately $90 \%$ as the meat temperature 213 increases from $23^{\circ} \mathrm{C}$ to $80^{\circ} \mathrm{C}$ (Murphy and Berrang, 2002). In accordance with this, the 214 decrease in protein content observed in our study paralleled the decrease in collagen composition.

216 The crude fat content of the empal gentong control samples was $6.26 \%$. Pre-cooking significantly reduced this value by $0.02 \%$ (T1), $0.28 \%$ (T2), and $1.13 \%$ (T3). In this study, pre-cooking prior to sterilization was a suitable way to reduce the fat content $(\mathrm{p}<0.05)$. 
As shown in Table 3, sensorial values in all treatment groups were not affected by precooking conditions $(\mathrm{p}>0.05)$. The sterilization process, with a temperature of $121^{\circ} \mathrm{C}$ and pressure of 10.15 psi, probably had a greater effect than pre-cooking on sensorial values. From this study, it could be concluded that sterilization at a high temperature and pressure has a greater influence on all sensory qualities of empal gentong meat than the duration

The authors declare no potential conflict of interest

Acknowledgements 
The author would like to thank the Indonesia Endowment Fund for Education (LPDP) for funding this research through the National Research Priority Program (RISTEK BRIN LPDP) 2020-2021.

\section{Author Contributions}

Conceptualization: Febrisiantosa A, Triyannanto E, Kusumaningrum A, Fauziah S. Data curation: Febrisiantosa A, Triyannanto E, Amri AF. Formal analysis: Febrisiantosa A, Fauziah S, Sulistyono EP, Dewandaru BM, Amri AF. Methodology: Febrisiantosa A, Fauziah S, Triyannanto E, Nurhikmat A, Susanto A. Investigation: Febrisiantosa A, Fauziah S, Kusumaningrum A, Sulistyono EP, Dewandaru BM. Writing - original draft, review \& editing: Febrisiantosa A, Triyyananto E, Fauziah S.

\section{References}

Anders S, Caswell JA. 2009. International Law and Trade Policy for Developing Countries. J Int Law Trade Policy 10:77-93. https://doi.org/10.22004/ag.econ.48794

Bouton PE, Harris P V. 1972. The effects of cooking temperature and time on some mechanical properties of meat. J Food Sci 37:140-144. https://doi.org/10.1111/j.1365-2621.1972.tb03404.x

Gómez I, Janardhanan R, Ibañez FC, Beriain MJ. 2020. The effects of processing and preservation technologies on meat quality: Sensory and nutritional aspects. Foods 9:1-30. https://doi.org/10.3390/foods9101416

Hamm R. 1972. Kolloidchemie des Fleischesdes Wasserbindungs-vermoegen des Muskeleiweisses in Theorie und Praxis. Verlag Paul Parey, Berlin.

Hamm R, Deatherage FE. 1960. Changes in Hydration, Solubility and Charges of 
Muscle Proteins During Heating of Meat. J Food Sci 25:587-610. https://doi.org/10.1111/j.1365-2621.1960.tb00004.x

Hearne LE, Penfield MJ, Goertz GE. 1978. Heating effects on bovine semitendinosus: shear, muscle fiber measurements, and cooking losses. J Food Sci 43:10-13

Hunt MC, Sørhelm O, Slinde E. 1999. Color and heat denaturation of myoglobin forms in ground beef. J Food Sci 64:847-851. https://doi.org/10.1111/j.13652621.1999.tb15925.x

Lawrie RA, Ledward D. 2006. Lawrie’s Meat Science: Seventh Edition

Manheem K, Benjakul S, Kijroongrojana K, Faithong N, Visessanguan W. 2013. Effect of pre-cooking times on enzymes, properties, and melanosis of Pacific white shrimp during refrigerated storage. Int Aquat Res 5:1-11. https://doi.org/10.1186/2008-6970-5-1

Moriyama Y, Takeda K. 2010. Critical temperature of secondary structural change of myoglobin in thermal denaturation up to $130^{\circ} \mathrm{C}$ and effect of sodium dodecyl sulfate on the change. J Phys Chem B 114:2430-2434. https://doi.org/10.1021/jp908700j

Muhlisin, Kim DS, Song YR, Cho YJ, Kim CJ, An BK, Kang CW, Lee SK. 2013. Effect of cooking time and storage temperature on the quality of home-made retort pouch packed Chuncheon Dakgalbi. Korean J Food Sci Anim Resour 33:737-743. https://doi.org/10.5851/kosfa.2013.33.6.737

Murphy RY, Berrang ME. 2002. Effect of Steam- and Hot-Water Post-Process Pasteurization on Microbial and Physical Property Measures of Fully Cooked Vacuum-Packaged Chicken Breast Strips. J Food Sci 67:2325-2329. https://doi.org/https://doi.org/10.1111/j.1365-2621.2002.tb09548.x

Rianti A, Novenia AE, Christopher A, Lestari D, Parassih EK. 2018. Ketupat as 
traditional food of Indonesian culture. J Ethn Foods 5:4-9.

https://doi.org/https://doi.org/10.1016/j.jef.2018.01.001 
Tables

336 Table 1. pH value, Tenderness, WHC, Cooking Loss and Instrumental Color of Meat RTE Empal Gentong Depending on Pre-cooking Conditions

\begin{tabular}{|c|c|c|c|c|}
\hline \multirow[b]{2}{*}{ Physical } & \multicolumn{4}{|c|}{ Pre-cooking conditions } \\
\hline & $\mathrm{C}$ & $\mathrm{T} 1$ & $\mathrm{~T} 2$ & T3 \\
\hline \multirow[t]{2}{*}{ Parameters } & (Not pre- & $\left(90^{\circ} \mathrm{C} / 10\right.$ & $\left(90^{\circ} \mathrm{C} / 20\right.$ & $\left(90^{\circ} \mathrm{C} / 30 \mathrm{~min}\right)$ \\
\hline & cooked) & $\min )$ & $\min )$ & \\
\hline pH value & $6.31 \pm 0.01^{\mathrm{b}}$ & $6.33 \pm 0.06^{\mathrm{b}}$ & $1^{\mathrm{b}}$ & $6.41 \pm 0.02^{\mathrm{a}}$ \\
\hline Tenderness & $6.40 \pm 0.20^{\mathrm{a}}$ & & $4.23 \pm 0.25^{\mathrm{b}}$ & $4.13 \pm 0.15^{\mathrm{b}}$ \\
\hline \multicolumn{5}{|l|}{$\left(\mathrm{kg} / \mathrm{cm}^{2}\right)$} \\
\hline $\mathrm{WHC}^{\mathrm{NS}}$ & $43.00 \pm 3.60$ & $42.33 \pm$ & $36.33 \pm 0.57$ & $34.00 \pm 7.00$ \\
\hline Cooking & - & $39.00 \pm 1.73^{b}$ & $41.67 \pm 1.15^{b}$ & $46.67 \pm 2.30^{\mathrm{a}}$ \\
\hline \multicolumn{5}{|l|}{ loss } \\
\hline CIE L* & $15.53 \pm 0.25^{\mathrm{b}}$ & $14.30 \pm 0.95^{\mathrm{c}}$ & $13.66 \pm 0.15^{\mathrm{c}}$ & $20.20 \pm 0.00^{\mathrm{a}}$ \\
\hline$a^{*}$ & $4.66 \pm 0.05^{\mathrm{ab}}$ & $4.43 \pm 0.25^{b}$ & $3.90 \pm 0.88^{b}$ & $5.43 \pm 0.11^{\mathrm{a}}$ \\
\hline$b^{* N S}$ & $14.53 \pm 0.05$ & $11.03 \pm 2.37$ & $12.40 \pm 2.07$ & $14.86 \pm 0.26$ \\
\hline
\end{tabular}

Results are expressed as mean \pm SD.

${ }^{a, b}$ Values within each row with different superscripts are significantly different $(\mathrm{p}<0.05)$.

NS Not significantly different $(\mathrm{p}>0.05)$ 

cooking Conditions

\begin{tabular}{ccccc}
\hline \multirow{2}{*}{$\begin{array}{c}\text { Proximate } \\
\text { Composition }\end{array}$} & $\mathrm{C}$ & $\mathrm{T} 1$ & $\mathrm{~T}$ Pre-cooking conditions \\
\cline { 2 - 5 }$(\%)$ & $($ Not pre- & $\left(90^{\circ} \mathrm{C} / 10\right.$ & $\left(90^{\circ} \mathrm{C} / 20 \mathrm{~min}\right)$ & $\left(90^{\circ} \mathrm{C} / 30 \mathrm{~min}\right)$ \\
& cooked $)$ & $\mathrm{min})$ & & $\mathrm{T} 3$ \\
\hline Moisture & $67.16 \pm 0.10^{\mathrm{a}}$ & $65.62 \pm 0.38^{\mathrm{b}}$ & $65.49 \pm 0.04^{\mathrm{b}}$ & $61.24 \pm 0.21^{\mathrm{c}}$ \\
Protein & $23.98 \pm 0.14^{\mathrm{a}}$ & $23.80 \pm 0.27^{\mathrm{a}}$ & $23.57 \pm 0.50^{\mathrm{ab}}$ & $23.14 \pm 0.09^{\mathrm{b}}$ \\
Fat & $6.26 \pm 0.10^{\mathrm{a}}$ & $6.24 \pm 0.06^{\mathrm{a}}$ & $5.98 \pm 0.03^{\mathrm{b}}$ & $5.13 \pm 0.10^{\mathrm{c}}$ \\
Collagen & $2.53 \pm 0.29^{\mathrm{a}}$ & $2.43 \pm 0.08^{\mathrm{a}}$ & $2.25 \pm 0.17^{\mathrm{b}}$ & $2.06 \pm 0.06^{\mathrm{b}}$
\end{tabular}

Results are expressed as mean \pm SD.

a,b,c Values within each row with different superscripts are significantly different $(p<0.05)$.

NS Not significantly different $(\mathrm{p}>0.05)$

2

54 


\begin{tabular}{|c|c|c|c|c|}
\hline \multirow{4}{*}{$\begin{array}{l}\text { Sensory } \\
\text { analysis }\end{array}$} & \multicolumn{4}{|c|}{ Pre-cooking conditions } \\
\hline & $\mathrm{C}$ & $\mathrm{T} 1$ & $\mathrm{~T} 2$ & $\mathrm{~T} 3$ \\
\hline & (Not pre- & $\left(90^{\circ} \mathrm{C} / 10\right.$ & $\left(90^{\circ} \mathrm{C} / 20\right.$ & $\left(90^{\circ} \mathrm{C} / 30 \mathrm{~min}\right)$ \\
\hline & cooked) & $\min )$ & $\min )$ & \\
\hline Color $^{\mathrm{NS}}$ & $3.92 \pm 0.49$ & $4.00 \pm 0.40$ & $3.96 \pm 0.53$ & $3.96 \pm 0.53$ \\
\hline Texture $^{\mathrm{NS}}$ & $3.48 \pm 0.82$ & $3.64 \pm 0.86$ & $3.76 \pm 0.96$ & $3.96 \pm 0.78$ \\
\hline Flavor ${ }^{\mathrm{NS}}$ & $3.72 \pm 0.61$ & $3.72 \pm 0.61$ & 0.59 & $3.80 \pm 0.76$ \\
\hline Taste $^{\mathrm{NS}}$ & $3.40 \pm 0.86$ & $3.44 \pm 0.86$ & $3.48 \pm 0.87$ & $3.40 \pm 0.76$ \\
\hline Acceptability & $3.60 \pm 0.64$ & $3.64 \pm 0.70$ & $3.72 \pm 0.54$ & $3.64 \pm 0.63$ \\
\hline NS & & & & \\
\hline
\end{tabular}

Results are expressed as mean \pm SD. 